\title{
Environmental risk factors related to the development of canine non-Hodgkin's lymphoma
}

\author{
Fatores de risco ambientais relacionados ao desenvolvimento do linfoma não Hodgkin canino
}

\author{
Danielle Almeida Zanini ${ }^{I}$ Katia Cristina KimuraII Adriana Tomoko Nishiya ${ }^{\mathrm{I}}$ Rodrigo Ubukata $^{\mathrm{II}}$ \\ Rafael Magdanelo Leandro ${ }^{\mathrm{IV}}$ Claudia Prado de Brito ${ }^{\mathrm{IV}}$ Márcia Trombetti $^{\mathrm{V}}$ Ana Carolina LagoaV \\ Thais Rodrigues Macedov ${ }^{\mathrm{V}}$ Lucas Campos de Sá Rodrigues ${ }^{\mathrm{VI}}$ Janaína Aparecida da Silva Rosendo \\ Helen Lyrio Arndt ${ }^{\mathrm{I}}$ Ricardo Augusto Dias ${ }^{\mathrm{VII}}$ Maria Lúcia Zaidan Dagli ${ }^{\mathrm{I}^{*}}$
}

\section{ABSTRACT}

This research aimed to investigate the possible risk factors associated with the development of canine non-Hodgkin's lymphoma. Owners of 83 dogs with non-Hodgkin's lymphoma and of 84 healthy dogs answered an epidemiological questionnaire. Dogs who lived outside of the house and within 100 meters of busy streets or avenues (defined as more than 50 vehicles per minute) had a higher risk for developing the disease (OR: 3.1, 95\% CI: 1.4$6.9, P=0.005)$. These results suggest that air pollution derived from vehicle traffic may be associated with the development of canine non-Hodgkin's lymphoma.

Key words: pollution, epidemiologic questionnaire, environmental factors, environmental tobacco smoke.

\section{RESUMO}

Este trabalho teve como objetivo investigar os possíveis fatores de risco ambientais, associados com o desenvolvimento de linfoma não-Hodgkin nos cães. Um questionário epidemiológico foi aplicado aos proprietários de 83 cães com linfoma não-Hodgkin e 84 proprietários de cães saudáveis. Os cães que viviam permanentemente no lado de fora da casa e em torno de 100 metros de ruas movimentadas ou avenidas (mais de 50 veículos por minuto) tiveram um maior risco de desenvolvimento da doença (OR: 3,1, IC 95\%: 1,4-6,9, $P=0,005)$. Esses resultados sugerem que a poluição do ar oriunda do tráfego veicular pode estar associada com o desenvolvimento de linfomas não-Hodgkin canino.

Palavras-chave: poluição, questionário epidemiológico, fatores ambientais, exposição ambiental ao tabaco.

\section{INTRODUCTION}

Non-Hodgkin's lymphomas (NHL) are malignant neoplasms that develop in most animal species. They have different histological subtypes and clinical features. NHL are the fifth most common form of cancer in humans and the third in dogs and its etiology is an unknown (FOURNEL-FLEURY et al., 1997; NOGAI et al., 2011).

Environmental factors have been investigated and are suspected in the development of Non-Hodgkin's lymphoma, especially the herbicide 2, 4-dichlorophenoxyacetic acid (GARABRANT, 2002), tobacco smoke (STAGNARO et al., 2004) and air pollution (GAVAZZA et al, 2001; PAZ et al., 2009; MARCONATO et al., 2009; GOUVEIA et al., 2010; MERLO et al., 2010; ABBA et al., 2011; CHAKRABORTY, 2011; KLIUCININKAS et al., 2011; LIOY et al., 2011).

Humans and domestic animals live under similar conditions and might develop similar cancers. Domestic animals are sentinels of potentially dangerous risks of humans due to short latency and, as such, are considered a useful tool for studying the epidemiology of cancer in humans (BACKER et al., 2001; KHANNA, 2006; BREEN

\footnotetext{
'Hospital Veterinário, Faculdade de Medicina Veterinária, Universidade Anhembi-Morumbi, São Paulo, SP, Brasil.

IIDepartamento da Patologia, Faculdade de Medicina Veterinária e Zootecnia (FMVZ), Universidade de São Paulo (USP), São Paulo, SP, Brasil. E-mail: mlzdagli@usp.br.*Autor para correspondência.

IIIPROVET, São Paulo, SP, Brasil.

${ }^{\text {IV }}$ Hospital Veterinário, Faculdade de Medicina Veterinária, Universidade de Santo Amaro (UNISA), São Paulo, SP, Brasil.

vHospital Veterinário Rebouças, São Paulo, SP, Brasil.

${ }^{\mathrm{V}}$ Hospital Veterinário, FMVZ, USP, São Paulo, SP, Brasil.

VIIDepartamento de Medicina Preventiva e Saúde Animal, FMVZ, USP, São Paulo, SP, Brasil.
} 
et al., 2008). This work aimed to conduct a survey in healthy dogs (controls) and in dogs with NHL by means of an epidemiological questionnaire applied to the dog owners, in order to evaluate independent variables that could possibly increase the risk of NHL in dogs.

\section{MATERIALS AND METHODS}

Study design

This study is a six-month retrospective case control recorded during March to August 2010. Five clinical, oncology and diagnostic veterinary centers participated in this research: Veterinary Hospital (HOVET) and Department of Pathology of the Faculty of Veterinary Medicine of the University of São Paulo (FMVZ-USP) (west of São Paulo); Veterinary Hospital of the University AnhembiMorumbi (east); Veterinary Hospital Rebouças (center-west); Veterinary Hospital of the University of Santo Amaro and the Veterinary Oncology PROVET (both in the south). To examine the impact of a variety of potential risk factors in dogs with nonHodgkin's lymphoma (NHL), a total of 83 NHL cases and 84 controls were included in the study. Cases of NHL and control group (without neoplasia) were diagnosed by histological and cytological methods (both residing in the same geographical areas and admitted to the same network of hospitals). Exclusion criteria included dogs diagnosed with other types of cancer and dogs diagnosed with more than one type of cancer.

Interviews

Eighty-three owners of dogs with NHL and 84 owners of control dogs were interviewed in person or by telephone using a questionnaire containing epidemiological data of the animal (gender, breed, age), lifestyle (food type, water type, exposure to different substances, proximity to magnetic waves) and data of the owner (lives in house or apartment, address, zip code, smoker or non-smoker, and cigarette type, among others). The questionnaire was applied from March 2010 to August, 2010, as showed in the figure 1 and 2.

\section{Statistical analysis}

The association of NHL with possible risk factors was assessed by chi-square test (univariate analysis). Variables that exhibited a $p$-value $\leq 0.20$ were submitted to logistic regression analysis (multivariate analysis) and variables that showed a p-value $<0.005$ were considered to be significant. All analyses were performed using SPSS software version 9.0 (SPSS, Inc., Chicago IL).

\section{RESULTS}

The mean age for NHL cases was 9.5 years (2-17 years) and 8.5 years (2-15 years) for the controls. There was no association between gender and case/ control status. Sixty-one percent of NHL cases $(n=51)$ were purebred dogs and $39 \%$ were mongrel dogs $(n=32)$. Of the control group, 64\% $(n=54)$ were purebred dogs and $36 \%$ were mongrel dogs $(n=35)$. The most common canine breeds bearing NHL were: Cocker Spaniel $(7 \%, \mathrm{n}=6)$; Rottweiler $(6 \%, \mathrm{n}=5)$; Boxer, Bull Terrier, Dachshund and Poodle (5\% each, $\mathrm{n}=4)$; Labrador $(4 \%, \mathrm{n}=3)$; Bernese Mountain Dog, Collie, Pit Bull, Irish Setter and Weimaraner (2.5\% each, $n=2$ ); Basset Hound, Beagle, Doberman, Dogue de Bordeaux, Golden Retriever, Siberian Husky, Doberman Pinscher, Schnauzer, Shar-Pei, Fox Terrier and Yorkshire ( $1 \%$ each, $\mathrm{n}=1)$.

The breeds in the control group were: Poodle (18\%, $\mathrm{n}=15)$; Cocker Spaniel $(10 \%, \mathrm{n}=8)$; Yorkshire $(6 \%, \mathrm{n}=5)$; Dachshund $(5 \%, \mathrm{n}=4)$; Rottweiler, Labrador, Dalmatian, Chihuahua, Boxer and Sheepdog (2.5\% each, $n=2)$; Staffordshire Terrier, Schnauzer, Doberman Pinscher, German Shepherd, Lhasa Apso, Dogo Argentino, Boston Terrier, Border Collie and Basset Hound ( $1 \%$ each, $n=1)$.

All variables showing a score of below $\mathrm{P}<0.20$ from the univariate analysis were included in the multivariate analysis, such as weight $(\mathrm{P}<0.001)$, use of Wi-Fi near the $\operatorname{dog}(\mathrm{P}<0.001)$, living in a house or apartment $(\mathrm{P}=0.01)$, use of incense, candles, fragrances, or scented oils $(\mathrm{P}=0.01)$, dogs that live inside or outside the house $(\mathrm{P}=0.02)$, use of antiparasitic drugs $(\mathrm{P}=0.02)$, dogs that live in the same owner's address $(\mathrm{P}=0.03)$, exposure to fires or barbecue ( $\mathrm{P}=0.03)$, contact with insecticides at home $(\mathrm{P}=0.04)$, dogs living within 100 meters of a busy street (defined as more than 50 vehicles per hour) $(\mathrm{P}=0.05)$, dogs that live on the ground with cement or other material $(\mathrm{P}=0.05)$, age $(\mathrm{P}=0.14)$, gender $(\mathrm{P}=0.14)$, castrated or not $(\mathrm{P}=0.14)$, dogs that have contact with herbicides at home $(\mathrm{P}=0.14)$ and use of shampoo with insecticide in the bath $(\mathrm{P}=0.2)$. From this result, the most statistically significant variables with $\mathrm{P} \leq 0.05$ were analyzed together in the multivariate regression analysis.

Multivariable regression showed that dogs who were permanently kept outdoors and lived within 100 meters of busy streets or avenues (more than 50 vehicles per minute) had significantly higher risk for developing NHL (odds ratio 3.1, 95\%, CI 1.4-6.9, $\mathrm{P}=0.001$ ) (Table 1). It was also noted that medium and large sized dogs, weighing over $10 \mathrm{~kg}(68 \%)$ had 


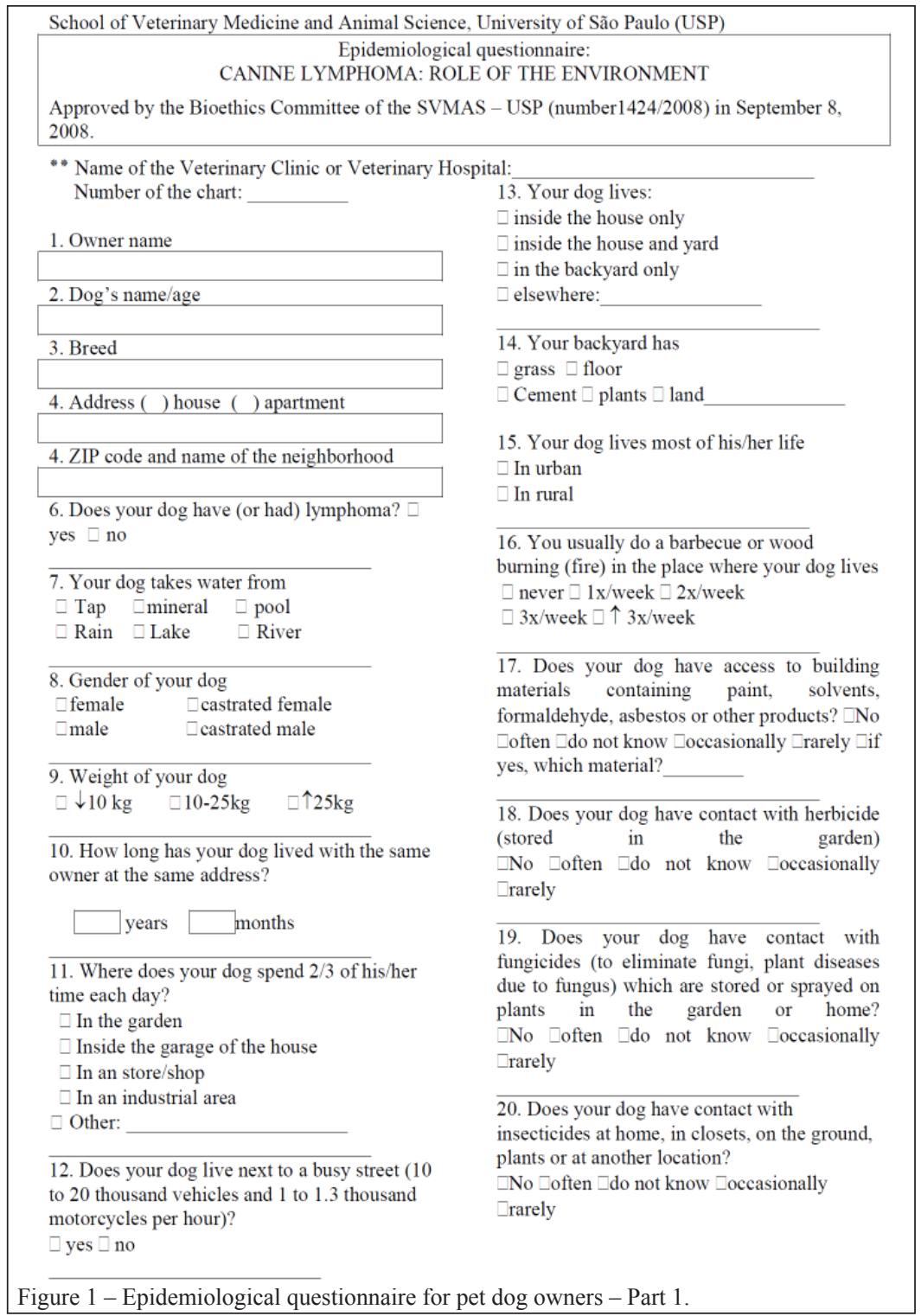

a higher risk for the development of NHL (odds ratio $3.8 ; 95 \%$, CI $1.8-8.0 ; \mathrm{P}<0.001)$.

\section{DISCUSSION}

Epidemiological data showed that middleaged and elderly dogs with non-Hodgkin's lymphoma (NHL) (mean age 8.5 years) were the most affected, similar to most studies (FOURNEL-FLEURY et al., 1997; WITHROW et al., 2006; NORTHS et al., 2009). No gender predisposition for the development of NHL was observed like other results (WITHROW et al., 2006; NORTHS et al., 2009). Breed was investigated for the predisposition to the development of NHL, indicating a high incidence in the Boxer, Bull Mastiff, Basset Hound, Saint Bernard and Bulldog (WITHROW et al., 2007; LURIE et al., 2008; NOGAI et al., 2011), differing from our result measured by the epidemiological questionnaire, in which the most affected breeds were Cocker Spaniel $(7 \%, \mathrm{n}=6)$; Rottweiler $(6 \%, \mathrm{n}=5)$; Boxer, Bull Terrier, Dachshund and Poodle (5\% each, $n=4)$ and Labrador $(4 \%, n=3)$. Although dogs that weigh more than $10 \mathrm{~kg}$ have a risk of developing NHL, we suggest that this association is not clear, because most dogs with or without lymphoma evaluated in this study were of medium to large size, and weighing over $10 \mathrm{~kg}$ was not considered in this investigation. The multicentric form of NHL and stages 3 and 4 comprised the greatest proportion, as shown in most of the studies, 


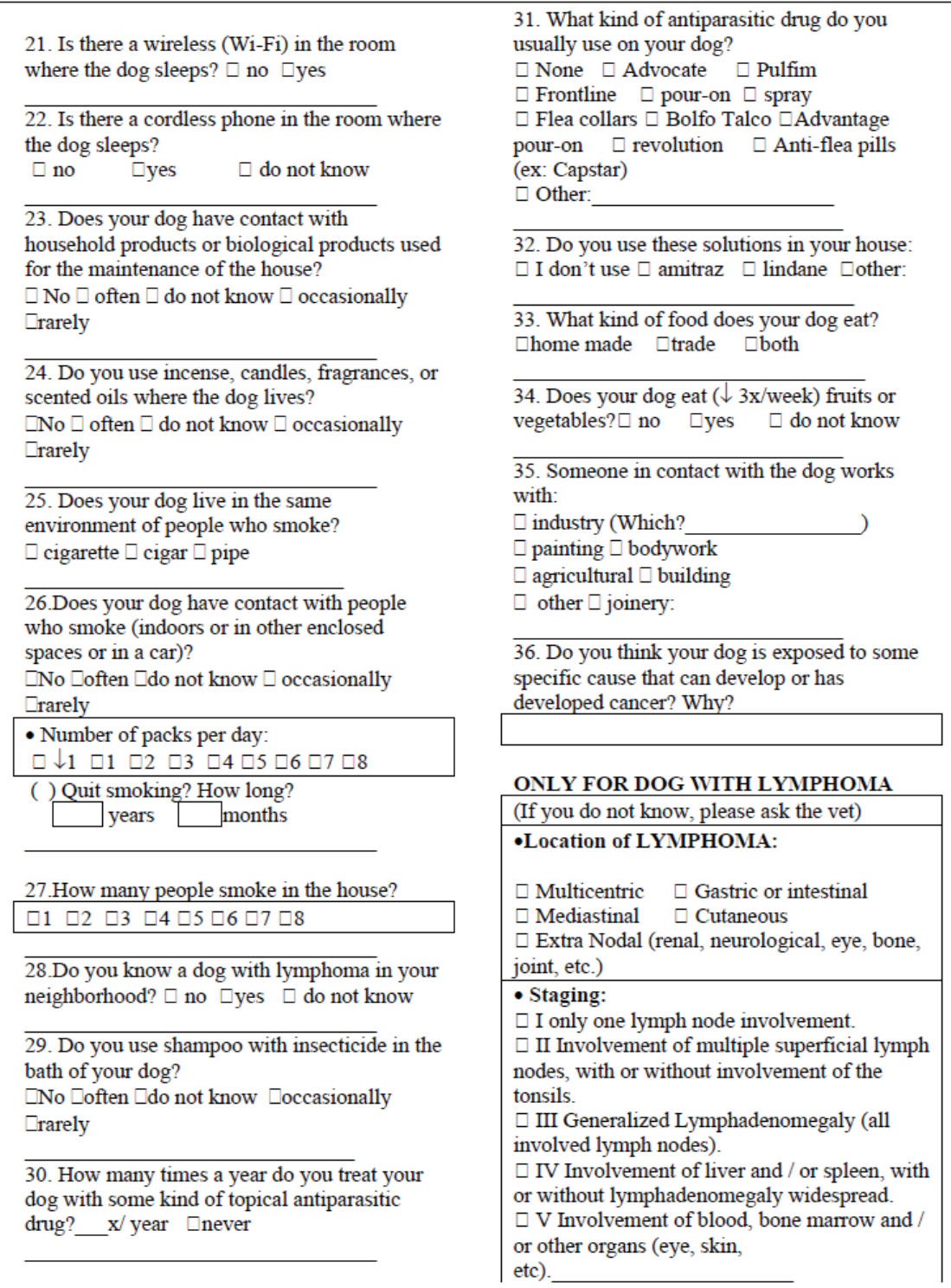

Figure 2 - Epidemiological questionnaire for pet dog owners- Part 2.

because usually dogs with NHL are treated late, with an advanced stage of disease (FOURNEL-FLEURY et al., 1997; WITHROW et al., 2006).

Most variables had no association with the risk of developing lymphoma. But some variables showed interesting results described below. Exposure to magnetic fields (MF) is reported to be a carcinogenic factor with an increased risk of developing leukemia and NHL in children (HARDELL et al., 2009; ELLIOTT et al., 2010) and dogs that spend 25\% of their time outdoors (REIF et al., 2005). Our result showed a relationship between the exposure to Wi-Fi and development of NHL on univariate analysis, but there was no association on multivariate analysis. This result might be considered a socio-economic factor because most people had Wi-Fi in their house or it was a confounding influence not considered in this investigation. Although there is a strong indication that dogs can be tobacco passive smokers living in the same place with their owner (ROZA \& VIEGAS, 2007), this study showed that there is no correlation between exposure to tobacco passive smoke and NHL in dogs, similar to the literature. On the other hand, passive smoker cats showed a higher risk to develop NHL (OR=2.14; 95\% CI: 1.2-4.5) (DENSON, 2003).

Air pollution is a serious and growing problem in megacities. This may lead to increased hospitalization for respiratory problems, decreased 
Table 1 - Potential risk factors associated with the development of canine lymphoma, São Paulo, Brazil (2010). Multivariate analysis.

\begin{tabular}{|c|c|c|c|}
\hline Risk factor & OR & $\mathrm{CI}$ & $\mathrm{P}$ \\
\hline $\begin{array}{l}\text { Dogs kept outdoors near a busy } \\
\text { avenue }\end{array}$ & 3,1 & $1.4-6.9$ & 0.005 \\
\hline Weight over $10 \mathrm{~kg}$ & 3.8 & $1.8-8.0$ & $<0.001$ \\
\hline
\end{tabular}

immune system, and cell damage caused by toxic components of air, which may contribute to increased risk of developing several types of cancers including NHL (CHAKRABORTY, 2011; KLIUCININKAS et al., 2011; LIOY et al., 2011). Many epidemiological studies in humans showed the association between particulate matter in the air and development of cancer, for example, in Tampa (CHAKRABORTY, 2011), Denmark (RAASCHOU-NIELSEN et al., 2011), Haifa Bay (EITAN et al., 2010), and India (ABBA et al., 2011). Vehicle pollution was the main contributor for benzene concentration in the atmosphere in the study areas (LIOY et al., 2011). Exposure to benzene has a potential to produce chromosome changes and other genetic changes of importance in NHL induction resulting in deletions and translocations (O'CONNOR et al., 1999). Street dust, vehicle exhaust, domestic heating and long-range transport may act not only as a source of particulate matter (PM), but also as a source of particle-bound polycyclic aromatic hydrocarbon (PAHs) and volatile organic compounds (VOCs) (KLIUCININKAS et al., 2011). The increased mortality from NHL and lung cancer in bus drivers and bus maintenance workers may be associated with long-term exposure to urban air pollution in Genoa (KLIUCININKAS et al., 2011). Another study showed association between NHL morbidity and residence near heavy roads $(\mathrm{P}<0.01)$ (PAZ et al., 2009).

The city of São Paulo has a significant environmental pollution, mainly caused by fourteen million cars and three million motorcycles (CETESB, 2011). The results of this study suggest that air pollution coming from vehicular traffic may be involved in the development of canine lymphomas, and potentially may also affect human health.

\section{CONCLUSION}

There are a few risk factors that have been identified in canine lymphoma. Statistical analysis observed that there is a significantly positive association between dogs that lived outside of the house around busy streets and avenues and increased risk of malignant lymphoma, suggesting that environmental pollution coming from vehicle traffic may be associated with the disease in dogs in São Paulo city. Considering the dogs as sentinels of humans, this result may be a clue to the development of human lymphoma too, requiring further investigation.

\section{ACKNOWLEDGEMENTS}

Danielle Almeida Zanini was the recipient of a Scientific Initiation fellowship from Fundação de Amparo à Pesquisa do Estado de São Paulo (FAPESP) (Proc. No. 2010/004187). Katia Cristina Kimura was the recipient of a PhD fellowship from FAPESP (Proc. No. 2008/54612-9). This study is part of the Thesis presented by Katia Cristina Kimura to the Experimental and Comparative Pathology Program of the School of Veterinary Medicine and Animal Science of the University of São Paulo, Brazil. The authors thank Rebouças Veterinary Hospital, Veterinary Hospital of the Anhembi Morumbi University, Veterinary Hospital of the University of Santo Amaro and Department of Clinical Oncology of PROVET for affording access to the data used in this investigation.

\section{BIOETHICS}

This project was approved by the Ethics Committee of the School of Veterinary Medicine and Animal Science of the University of São Paulo, Brazil, number is $1424 / 2008$.

\section{REFERENCES}

ABBA, E.J. et al. Fine aerosol and PAH carcinogenicity estimation in outdoor environment of Mumbai City, India. Internal Journal Environmental Health Research, v.22, p.134-49, 2011. Avaliable from: <http://www.tandfonline.com/doi/pdf/1 0.1080/09603123.2011.613112 >. Accessed: dez 15, 2012. doi: $10.1080 / 09603123.2011 .613112$.

BACKER, L.C. et al. Pet dogs as sentinels for environmental contamination. Science Total Environmental, v.274, p.161169, 2001. Avaliable from: <http://www.sciencedirect.com/ science/article/pii/S0048969701007409> Accessed: fev 24, 2012. doi:http://dx.doi.org/10.1016/S0048-9697(01)00740-9.

BREEN, M.; MODIANO, J. Evolutionarily conserved cytogenetic changes in hematological malignancies of dogs and humans--man and his best friend share more than companionship. Chromosome Research, v.16, p.145-154, 2008. Avaliable from: <http://link. springer.com/article/10.1007\%2Fs10577-007-1212-4>. Accessed: jan 15, 2012. doi:10.1007/s10577-007-1212-4.

[CETESB] Companhia de Tecnologia de Saneamento Ambiental. São Paulo: Relatório de qualidade do ar no estado de São Paulo, 2004. 137p. Acesso em: 24 jan. 2005. Online. Disponível em: $<$ http://www.cetesb.sp.gov.br/ar/qualidade-do-ar/31-publicacoese-relatorios $>$.

CHAKRABORTY, J. Cancer risk from exposure to hazardous air pollutants: spatial and social inequities in Tampa Bay, Florida. Internal Journal Environmental Health Research, v.22, p.16583, 2011. Avaliable from: <http://www.tandfonline.com/doi/ab 
s/10.1080/09603123.2011.628643?url_ver=Z39.88-2003\&rfr id $=$ ori:rid:crossref.org\&rfr dat $=$ cr pub\% $\%$ dpubmed $>$. Accessed: march 22, 2012. doi: $10.1080 / 09603123.2011 .628643$.

DENSON, K. Re: environmental tobacco smoke and risk of malignant lymphoma in pet cats. American Journal Epidemiology, v.158,p.1227-1228, 2003. Avaliable from: <http:// aje.oupjournals.org/cgi/doi/10.1093/aje/kwf044> Accessed: march 20, 2012. doi: 10.1093 .

EITAN, O. et al. Spatial analysis of air pollution and cancer incidence rates in Haifa Bay, Israel. Science Total Environmental, v.408, p.4429-4439, 2010. Avaliable from: <http://linkinghub. elsevier.com/retrieve/pii/S0048-9697(10)00636-4>.Accessed: jan 14, 2012. doi: 10.1016/j.scitotenv.2010.06.031.

ELLIOTT, P. et al. Mobile phone base stations and early childhood cancers: case-control study. Britisch Medical Journal, v.340, p.3077, 2010. Avaliable from: <http://www.bmj.com/cgi/pmidlo okup?view=long\&pmid $=20570865>$. Accessed: $\operatorname{dez} 3$ 3, 2011. doi: 10.1136/bmj.c3077.

FOURNEL-FLEURY, C. et al. Cytohistological and immunological classification of canine malignant lymphomas: comparison with human non-Hodgkin's lymphomas. Journal Comparative Pathology, v.117, p.35-59, 1997. Avaliable from: <http://linkinghub.elsevier.com/retrieve/pii/ S0021997597800655>.Accessed: nov 12, 2011. doi: 10.1016/ S0021-9975(97)80065-5.

GAVAZZA, A. et al. Association between canine malignant lymphoma, living in industrial areas, and use of chemicals by dog owners. Journal Veterinary Internal Medicine, v.15, p.190-195, 2001. Avaliable from: <http://openurl.ebscohost. com/linksvc/linking. asp $x$ ? genre $=$ article $\&$ sid $=$ PubMed\&is $\mathrm{sn}=0891-6640 \&$ title $=\mathrm{J} \% 20$ Vet $\% 20$ Intern $\% 20$ Med $\&$ volume $=1$ $5 \&$ issue $=3$ \& spage $=190 \&$ atitle $=$ Association $\% 20$ between $\% 20$ canine $\% 20$ malignant $\% 20$ lymphoma, $\% 20$ living $\% 20 \mathrm{in} \% 20$ industrial $\% 20$ areas, $\% 20$ and $\% 20$ use $\% 20$ of $\% 20$ chemicals $\% 20$ by $\% 20 \operatorname{dog} \% 20$ owners. \&aulast $=$ Gavazza\&date $=2001>$. Accessed: nov 23, 2011. doi: 10.1111/j.1939-1676.2001. tb02310.x

GARABRANT, D.H.; PHILBERT, M.A. Review of 2,4-dichlorophenoxyacetic acid (2,4-D) epidemiology and toxicology. Critical Reviews in Toxicology, v.32, n.4, p.23357, 2002. Avaliable from: <http://informahealthcare.com/doi/ abs/10.1080/20024091064237\%20>. Accessed: nov 23, 2011. doi: http://dx.doi.org/10.1080/20024091064237.

GOUVEIA, N.; PRADO, R. Spatial analysis of the health risks associated with solid waste incineration: a preliminary analysis. Revista Brasileira de Epidemiologia, v.13, p.3-10, 2010. Avaliable from: $\quad<$ http://www.scielo.br/scielo.php?script=sci arttext\&pid $=\mathrm{S} 1415-790 X 2010000100001 \& \operatorname{lng}=\mathrm{en} \& \mathrm{nrm}=\mathrm{i}$ so\&tlng=en>. Accessed: fev 23, 2012. doi: 10.1590/S1415790X2010000100001.

HARDELL, L. et al. Epidemiological evidence for an association between use of wireless phones and tumor diseases. Pathophysiology, v.16, p.113-122, 2009. Avaliable from: <http:// linkinghub.elsevier.com/retrieve/pii/S0928-4680(09)00009-1>. Accessed: out 22, 2011. doi: 10.1016/j.pathophys.2009.01.003.

KHANNA, C. et al. The dog as a cancer model. Nature Biotechnology, v.24, p.1065-1066, 2006. Avaliable from: $<\mathrm{http}: / /$ dx.doi.org/10.1038/nbt0906-1065b>. Accessed: march 23, 2011. doi:10.1038/nbt0906-1065b.

KLIUCININKAS, L. et al. Indoor and outdoor concentrations of fine particles, particle-bound PAHs and volatile organic compounds in Kaunas, Lithuania. Journal of Environmental Monitoring, v.13, p.182-91, 2011. Avaliable from: $<\mathrm{http}: / / \mathrm{dx}$.doi. org/10.1039/c0em00260g > Accessed: june 13, 2011. doi: 10.1039/ $\mathrm{c} 0 \mathrm{em} 00260 \mathrm{~g}$.

LIOY, P.J. et al. HEI Health Review Committee. Personal and ambient exposures to air toxics in Camden, New Jersey. Research report (Health Effects Institute), v.160, p.3-127, 2011. Avaliable from: <http://eohsi.rutgers.edu/files/HEI\%20Full.pdf >. Accessed: sept 22, 2011. PMDI:22097188.

LURIE, D. et al. Immunophenotypic and cytomorphologic subclassification of T-cell lymphoma in the boxer breed. Veterinary Immunology and Immunopathology, v.125, p.102110, 2008. Avaliable from: <http://linkinghub.elsevier.com/ retrieve/pii/S0165-2427(08)00195-5>. Accessed: july 3, 2012. doi: 10.1016/j.vetimm.2008.05.009.

MARCONATO, L. et al. Association between waste management and cancer in companion animals. Journal Veterinary Internal Medicine, v.23, p.564-569, 2009. Avaliable from: $<\mathrm{http}: / / \mathrm{dx}$.doi.or g/10.1111/j.1939-1676.2009.0278.x>. Accessed: jan 23, 2011. doi: 10.1111/j.1939-1676.2009.0278.

MERLO, D.F. et al. A historical mortality study among bus drivers and bus maintenance workers exposed to urban air pollutants in the city of Genoa, Italy. Occupational and Environmental Medicine, v.67, p.611-619, 2010. Avaliable from: $<\mathrm{http}: / / \mathrm{oem} . b m j$. com/cgi/pmidlookup?view=long\&pmid=20576925>. Accessed: fev 2, 2011. doi: 10.1136/oem.2009.050377.

NOGAI, H.B. et al. Pathogenesis of non-Hodgkin's lymphoma. Journal Clinical Oncology, v.29, p.1803-1811, 2011. Avaliable from: $<$ http://jco.ascopubs.org/content/29/14/1803.abstract>. Accessed: sept 22,2011. doi: 10.1200/JCO.2010.33.3252.

NORTHS, S.; BANKS, T. Introduction to small animal oncology. Londres: Saunders Elsevier, 2009. 304p.

O'CONNOR, S.R. et al. Benzene and non-Hodgkin's lymphoma. Journal of Pathology, v.189, p.448-53, 1999. Avaliable from: $<$ http://onlinelibrary.wiley.com/doi/10.1002/(SICI)10969896(199912)189:4\%3C448::AID-PATH458\%3E3.0.CO;2-K/ pdf>. Accessed: jan 3, 2010. doi:10.1002/(SICI)10969896(199912)189:4<448::AID-PATH458>3.0.CO;2-K.

PAZ, S. et al. Non-Hodgkin Lymphoma (NHL) linkage with residence near heavy roads--a case study from Haifa Bay, Israel. Health Place, v.15, p.636-641, 2009. Avaliable from: <http:// linkinghub.elsevier.com/retrieve/pii/S1353-8292(08)00120-2>. Accessed: jan 22, 2011. doi: 10.1016/j.healthplace.2008.10.004.

RAASCHOU-NIELSEN, O. et al. Air pollution from traffic and cancer incidence: a Danish cohort study. Environmental Health, v.19, p.10-67, 2011. Avaliable from: <http://www.ncbi.nlm.nih. gov/pmc/articles/PMC3157417/>. Accessed: ago 2, 2011.doi: 10.1186/1476-069X-10-67.

REIF, J.S. et al. Residential exposure to magnetic fields and risk of canine lymphoma. American Journal Epidemiology, v.141, p.352-359, 2005. Avaliable from: <http://aje.oxfordjournals.org/ 
cgi/pmidlookup?view=long\&pmid=7840113>. Accessed: ago 2, 2011.doi: 10.1186/1476-069X-10-67. doi: 10.1093/aje/141.4.352.

ROZA, M.R.; VIEGAS, C.A. The dog as a passive smoker: effects of exposure to environmental cigarette smoke on domestic dogs. Nicotine Tobacco Research, v.9, n.11, p.1171-1176, 2007. Avaliable from: <http://ntr.oxfordjournals.org/cgi/pmidl ookup?view=long\&pmid=17978991>. Accessed: ago 2, 2011. doi:10.1080/14622200701648391.
STAGNARO, E. et al. Non Hodgkin's lymphoma and type of tobacco smoke. Cancer Epidemiology Biomarkers Prevention, v.13, n.3, 431-437, 2004. Avaliable from: <http://cebp.aacrjournals.org/ content/13/3/431.full.pdf $>$. Accessed: sept 3, 2011. IS SN: $1538-7755$.

WITHROW, S.J.; VAIL, D.M. Small animal clinical oncology. 4.ed. St. Louis: Saunders, 2006. 864p. 